\title{
A NEW VACUUM-OPERATED STRESS-PROVIDING INSTRUMENT THAT APPLIES STATIC OR VARIABLE DURATION CYCLIC TENSION OR COMPRESSION TO CELLS IN VITRO
}

\author{
ALBERT J. BANES ${ }^{1,2, \bullet, ~ J E R O M E ~ G I L B E R T ~}{ }^{1}$, DUANE TAYLOR ${ }^{2}$ AND \\ OLIVIER MONBUREAU ${ }^{2}$ \\ ${ }^{1}$ Department of Surgery and ${ }^{2}$ Dental Research Center, 253 Clinical Sciences Building \\ $229 H$, University of North Carolina, Chapel Hill, NC 27514, U.S.A.
}

\section{SUMMARY}

An instrument providing cyclic stress to cells cultured in vitro has been developed. The unit uses a vacuum to deform a plastic Petri dish yielding $0.13 \%$ compression to cells on the inner surface, measured by strain gauge recordings. A regimen of $25 \mathrm{~s}$ stress and $5 \mathrm{~min}$ relaxation induced no significant change in synthesis of a $45 \times 10^{3} M_{\mathrm{r}}$ protein that comigrates with actin, whereas a $52 \times 10^{3} \mathrm{M}_{\mathrm{r}}$ protein that comigrated with tubulin decreased from $12.7 \pm 0.451 \%$ of the total protein synthesized in control, static cells to $8.53 \pm 0.182 \%$ in stressed cells. The unit may have a broad application in monitoring biochemical changes in response to stress in cells such as muscle, lung, tendon, ligament and bone that are normally subjected to tension or compression.

\section{INTRODUCTION}

Certain cell types respond in vitro to applied mechanical forces; 'wounding' cells by producing a cut in the epidermis or a monolayer of cells elicits cell division (Ooka, 1970; Ristow, Holley \& Messmer, 1978).

Arem \& Madden (1976) used a magnetic field in vivo to apply cyclic force ( 3 or 14 weeks after implantation for $6 \mathrm{~h} /$ day for 4 weeks) to scar collagen that accrued between two sponge implants, with metal bars inserted in the implants that repulsed each other when the field was activated. They concluded that young scars subjected to stress had less bursting strength than unstressed scars of similar age, but indicated no detectable differences in burst strength for 18-week-old scars. They did report dramatic morphological changes, indicating an increase up to $7 \cdot 6$-fold in distance between sponge implants (Arem \& Madden, 1976).

Applying tension to an osteoblast monolayer via an orthodontic device glued to the bottom of a Petri dish stimulates cells to produce cAMP and prostaglandin $E_{2}$ during the first 20 min post-stimulation, and then to divide (Somjen, Binderman, Berger \&

- Author for correspondence.

Key words: stress-providing instrument, cell compression. 
Harall, 1980). In vivo, cells are constantly subjected to tension and compression. However, no investigators have studied the effects of cyclic forces on the biochemical response of cells in vitro.

A simple, stress-producing instrument has been developed, to apply compression or tension of variable strength and duration to cells in vitro (Fig. 1). This stress unit is currently in use to determine the effects of cyclic loading on cells in culture that are subjected to tension in vivo. For the purpose of demonstrating the utility of the unit, the results of experiments with protein synthesis in cultured tendon cells are presented.

\section{MATERIALS AND METHODS}

The stress unit consists of a Plexiglas ${ }^{\text {TM }}$ manifold, $41.59 \mathrm{~cm} \times 23.82 \mathrm{~cm} \times 3.02 \mathrm{~cm}$ bearing six gasketed vacuum ports (Fig. 1A,B). Each port contains two concentric stations, one that accepts a $60 \mathrm{~mm}$ and one a $100 \mathrm{~mm}$ diameter plastic Petri dish. The rubber gaskets are recessed $1.5 \mathrm{~mm}$ in the Plexiglas ${ }^{\text {TM }}$ and the gasket remains $1.5 \mathrm{~mm}$ above the plane of the vacuum port. Gaskets receive a coat of vacuum grease and then plates are centred over the ports. One side of the unit contains a metered fitting to which vacuum can be applied and measured, the other side has a bleed valve used to adjust the vacuum level. The stress unit fits onto a tray inside a standard $\mathrm{CO}_{2}$ incubator, Vacuum and bleed hoses are led through the vent hole at the top of the incubator to avoid disturbing the internal atmosphere. The vacuum hose is valved and connected at one fitting to house vacuum, and at the other to a timer. The timer is variable and can be set for $0 \cdot 1-100 \mathrm{~s}, \min$ or $h$ for force application (timer station 1) or relaxation (timer station 2). Selection of the vacuum mode is controlled by timer station 1 ; the lines and manifold require $5 \mathrm{~s}$ to reach a gauge pressure of 12 , then the culture-plate bottoms are drawn flush with the vacuum port opening, achieving a maximum deflection of $1.5 \mathrm{~mm}$, at the plate centre. When the vacuum is released the plates return to their original conformation for a chosen period of relaxation.

Plates have been cycled for $25 \mathrm{~s}$ of stress with $5 \mathrm{~min}$ of relaxation for over 3500 cycles. Falcon plastic Petri dishes have been used in all experiments and have resisted deformation or breaking. Stress lines appear in the central portion of plates in long-term experiments; however, these lines do not appear to interfere with cell morphology.

\section{Surface strain measurement}

Two strain gauges were mounted on the internal surface of a $100 \mathrm{~mm}$ diameter plastic Petri dish. One gauge was mounted $5 \mathrm{~mm}$ and the other $20 \mathrm{~mm}$ from the centre of the plate. Both were oriented

Fig. 1. The three components that constitute the tension unit are the solenoid valve (SV), timer and vacuum unit. House vacuum is applied to the evacuation port and regulated by adjusting the inlet valve so that the vacuum gauge reads 12 . This vacuum is sufficient to deflect the bottom of the plastic dish $1.5 \mathrm{~mm}$ from the resting plane, creating a compression of $0.13 \%$ on the inside surface of the plastic. When the vacuum is released, external air enters the unit through the inlet valve allowing the plate bottom to return to the resting plane. The timer is capable of allowing variability in duration of both stress and relaxation from seconds to hours. In $\mathrm{A}$, the timer is set to deliver $25 \mathrm{~s}$ of stress (position 1, units $=\mathrm{s}$, factor $=1$ ) and $5 \mathrm{~min}$ of relaxation (position 2 , units $=\min$, factor $=1$ ). The countdown display indicates the time remaining ( 2 digits) and the number of cycles (4 digits). The $100 \mathrm{~mm}$ diameter plastic culture dishes are seated on rubber gaskets coated lightly with vacuum grease. $\mathrm{B}$. A line drawing indicating that the stress unit fits inside a standard $\mathrm{CO}_{2}$ incubator. The magnification of the plastic plate on the Plexiglas ${ }^{\mathrm{TM}}$ manifold shows the $1.5 \mathrm{~mm}$ deflection of the plate bottom when vacuum is applied, providing $0.13 \%$ compression to the internal surface of the dish. 

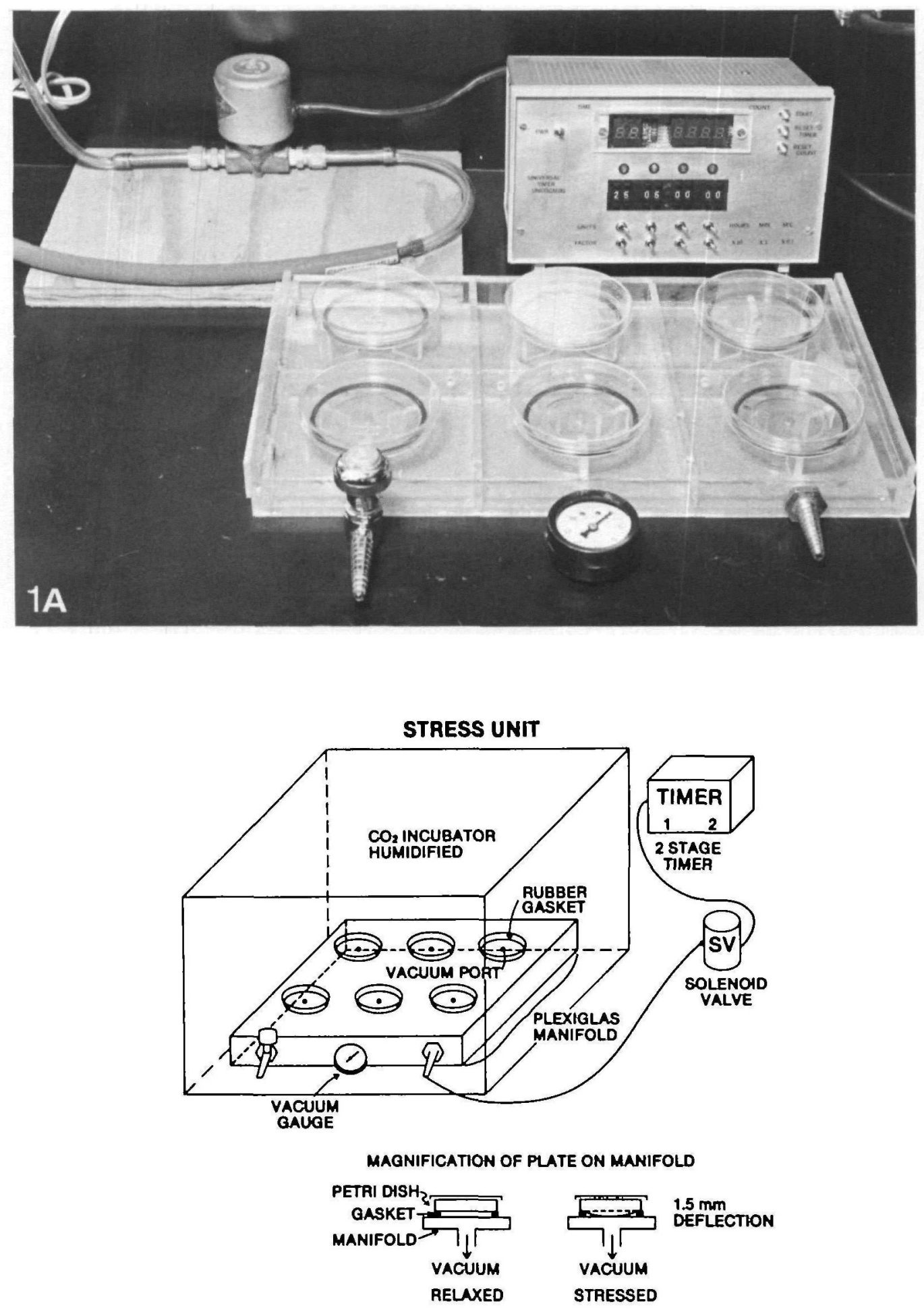

Fig. 1B 
in a radial direction. Individual leads from each gauge were connected separately to a digital strain indicator. The plate was deformed on the vacuum unit, and the strain was read directly from the digital strain indicator.

\section{Cell culture}

Flexor hallucis longus tendons were removed from 6-week-old White Leghorn chickens. The middle portion of the tendon was used minus the origin and insertion regions. Tendon was cut into $0.1 \mathrm{~mm}^{3}$ pieces with scissors in Hanks' salts solution with $20 \mathrm{~mm}$-Hepes (pH 7.2) (HSS), antibiotics and $0.5 \mathrm{mg} / \mathrm{ml}$ of collagenase. Tissue was incubated for $8 \mathrm{~h}$ with shaking at $37^{\circ} \mathrm{C}$. Released cells were sedimented and washed twice in medium and plated at $500 \times 10^{3}$ cells per $100 \mathrm{~mm}$ dish (Primaria culture plates, Beckton Dickinson Co., 1950 Williams Dr., Oxnard, CA 93030). Cells at passage 5 were seeded in $100 \mathrm{~mm}$ dishes at $500 \times 10^{3}$ cells $/$ dish, allowed to attach for $24 \mathrm{~h}$, then one group was placed in the stress unit ( $n=5 ; 25 \mathrm{~s}$ tension, $5 \mathrm{~min}$ relaxation) and the other under static conditions in the same $\mathrm{CO}_{2}$ incubator $(n=5)$. Cells were cultured for 5 days in minimum essential medium containing $10 \%$ heat-inactivated calf serum, $20 \mathrm{~mm}-\mathrm{Hepes}(\mathrm{pH} 7 \cdot 2)$ and antibiotics, and the medium was changed on days 2,3 and 5.

\section{Biochemistry}

On day 5 cells were approximately $80-90 \%$ confluent. Cells were washed with HSS twice then incubated with $1 \mathrm{ml}$ of $\mathrm{HSS}$ containing $0.4 \mathrm{mM}$-ascorbate and $50 \mu \mathrm{Ci}$ of $\left[{ }^{35} \mathrm{~S}\right]$ methionine (NEG $009 \mathrm{H}$ New England Nuclear, $400 \mathrm{Ci} / \mathrm{mmol}$, Boston, MA) for $2 \mathrm{~h}$ at $37^{\circ} \mathrm{C}$ in $5 \% \mathrm{CO}_{2}$ in a humidified incubator. Cells that were in the tension groups were radiolabelled under non-tension conditions, as was the control group. After $2 \mathrm{~h}$, plates were placed on ice and $1 \mathrm{ml}$ of $10 \%$ trichloroacetic acid $/ 0.025 \%$ tannic acid (TCA-TA) was added to stop incorporation and precipitate protein. Cells and fluids were scraped from the plates, transferred to glass tubes, sedimented and washed exhaustively with ice-cold $5 \%$ TCA-TA to remove unincorporated radioisotope. Sample pellets were extracted twice with diethyl ether, dried in vacuum on ice, then solubilized in $200 \mu \mathrm{l}$ of $4 \mathrm{M}$ urea, $2 \%$ sodium dodecyl sulphate (SDS), $2 \% 2$-mercaptoethanol and $0.05 \mathrm{~m}$-Tris (pH 6.8) at $100^{\circ} \mathrm{C}$ for $60 \mathrm{~s}$.

\section{Gel electrophoresis}

The Tris-borate method of Sykes \& Bailey (1971) was used. Slab gels $(10 \mathrm{~cm})$ of $10 \%$ acrylamide/SDS with a $4 \%$ stacking gel were used. Equivalent amounts $\left(200 \times 10^{3}\right.$ c.p.m.) of radioactivity were added to each lane of the gel and electrophoresis was performed for $3 \mathrm{~h}$ at $150 \mathrm{~V}$. Gels were stained with Coomassie Blue, destained, scanned densitometrically with a Hoefer GS300 scanning densitometer (Hoefer Scientific Instruments, San Francisco, CA) and the waveform was stored and integrated using a chromatography software package and an Apple computer (Dynamic Solutions Inc., Pasadena, CA). The gel was then infiltrated with fluors, dried and an autoradiogram was prepared (Bonner \& Laskey, 1974). The autoradiogram was scanned and the bands were integrated as above.

\section{RESULTS}

Strain readings from both the inner and outer strain gauges on the test Petri dish indicate that the internal surface of the dish experiences an average compressive strain of $0 \cdot 13 \%$ at maximum downward deflection.

Fig. 2. A. Depicts a cross-section of a $60 \mathrm{~mm}$ plastic culture plate held in tension for $24 \mathrm{~h}$, while filled with an acrylic resin. The polymerized resin retained the shape of the plate under compression. Maximum deflection was $1.5 \mathrm{~mm}$, associated with a stretch of no more than $0.13 \%$. B. Indicates circular stress lines evident in the plastic of a $100 \mathrm{~mm}$ plate after 3500 cycles at $25 \mathrm{~s}$ stress (compression) and $5 \mathrm{~min}$ relaxation. C. Indicates stress lines in a $60 \mathrm{~mm}$ plate under the same conditions as for $\mathrm{B}$. 

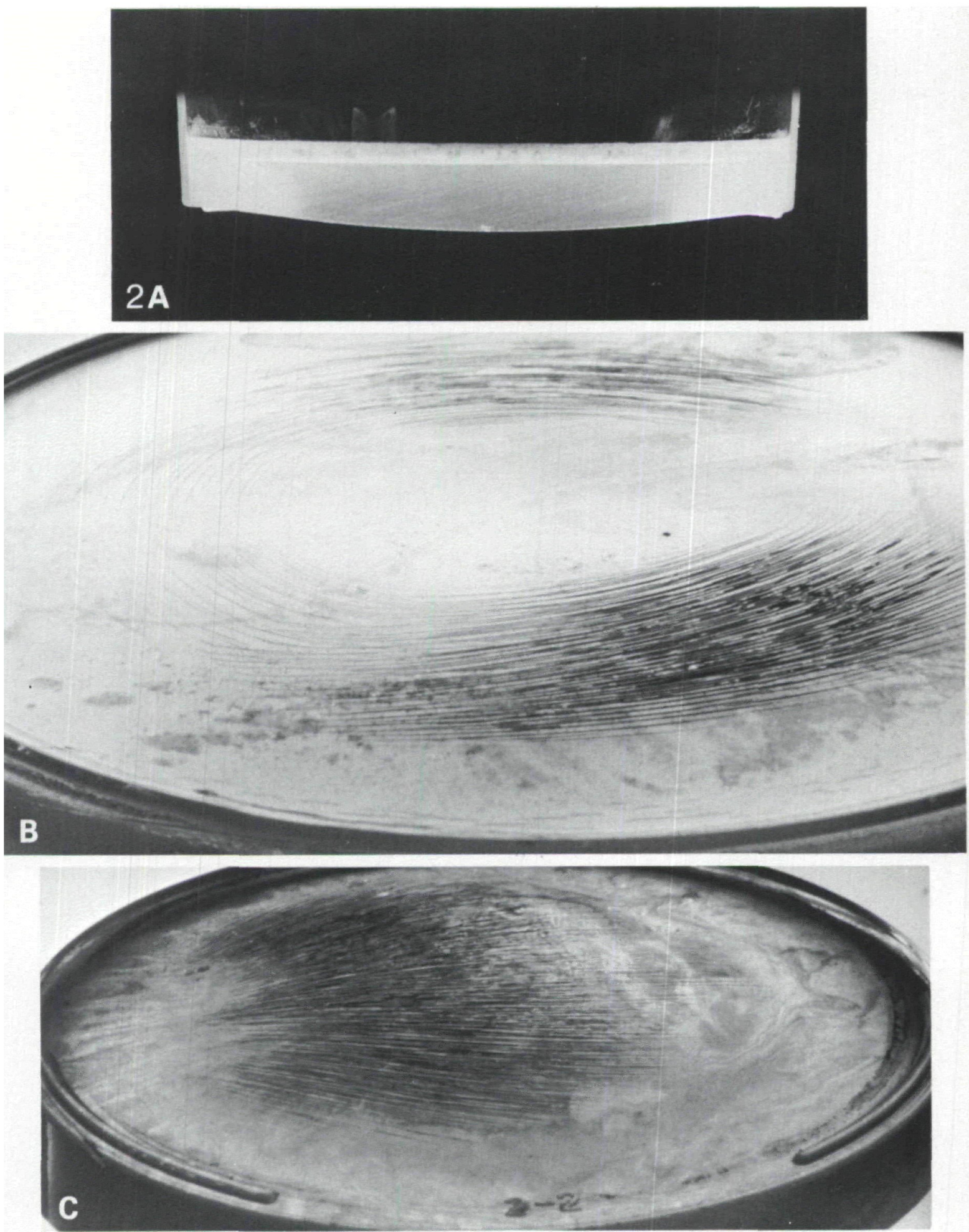

Fig. 2 
Fig. $2 \mathrm{~A}$ indicates the deflection observed in a cross-section of a typical culture plate on the stress unit that retained its position while in stress due to polymerization of an added acrylic resin. Physical limitations of the polystyrene preclude a deformation of more than $0.5-1 \%$ before plastic deformation.

Fig. 2B and $\mathrm{C}$ indicate culture dishes, diameters 100 and $60 \mathrm{~mm}$, respectively, that were subjected to 3500 cycles of tension of $25 \mathrm{~s}$ duration with 5 -min relaxation intervals. Lines of strain are clearly observed, which appear circular in the $100 \mathrm{~mm}$ plate and more linear in the $60 \mathrm{~mm}$ plate.

Data in Table 1 indicate that synthesis of certain proteins is altered in tendon cells subjected to compression compared with control, non-stressed cultures. In particular, a band at $45 \times 10^{3} M_{\mathrm{r}}$ is not changed significantly in stressed cultures compared to the control counterparts. This protein comigrates with actin. A band at $52 \times 10^{3} M_{\mathbf{r}}$ that comigrates with tubulin is decreased from $12.7 \pm 0.451 \%$ of the total protein in the static cultures, to $8.53 \pm 0.182 \%$ in the stressed cultures $(P<0.001,0.1 \%$ compression, 1300 cycles, $25 \mathrm{~s}$ stress, 5 min relaxation).

Table 1. Semi-quantitation of tubulin and actin from tendon internal fibroblasts under control or compression in vitro

\begin{tabular}{|c|c|c|c|c|c|c|}
\hline & \multirow[b]{2}{*}{$N^{*}$} & \multicolumn{2}{|c|}{ Tubulin } & \multicolumn{2}{|c|}{ Actin } & \multirow{2}{*}{$\begin{array}{l}\text { Ratio } \\
\mathrm{T} / \mathrm{A}\end{array}$} \\
\hline & & Areat & \% Total & Area & \$o Total & \\
\hline Control & 5 & $\begin{array}{c}0.363937 \pm \\
0.0024\end{array}$ & $\begin{array}{c}12 \cdot 7 \pm \\
0.451\end{array}$ & $\begin{array}{c}0.020888 \pm \\
0.00201\end{array}$ & $\begin{array}{c}7 \cdot 27 \pm \\
0.487\end{array}$ & $1 \cdot 77 \pm 0 \cdot 116$ \\
\hline Compression & 5 & $\begin{array}{c}0.020368 \pm \\
0.007479 \\
P<0.022\end{array}$ & $\begin{array}{c}8.53 \pm \\
0 \cdot 182 \\
P<0.001\end{array}$ & $\begin{array}{l}0.02302 \pm \\
0.001976 \\
\text { NS }\end{array}$ & $\begin{array}{c}8.32 \pm \\
0.254 \\
P<0.026\end{array}$ & $1.02 \pm 0.050$ \\
\hline $\begin{array}{l}\text { Control/ } \\
\text { Compressio }\end{array}$ & & $1 \cdot 79$ & $1 \cdot 49$ & 0.907 & 0.874 & \\
\hline
\end{tabular}

Cells were isolated from the internal part of tendon as described in Materials and Methods. These cells represented the fusiform, fibroblastic cell population. Compression force $(0 \cdot 13 \%)$ was applied to the cultured cells by inducing a downward deflection in the bottom of the plastic plate with a vacuum applied at the central portion of the plate, whose circumference rested on a greased rubber gasket.

- $N$ refers to the number of cultures used in each group.

† Area refers to the area beneath the curve for bands from an autoradiogram of $\left[{ }^{35} \mathrm{~S}\right]$ methioninelabelled proteins separated in an SDS/polyacrylamide gel. Means and standard deviation of the means are given for control or experimental cells.

\section{DISCUSSION}

An instrument has been devised that is capable of delivering static or cyclic compression or tension of variable duration to cells cultured in vitro. A deformation of no greater than $0.5-1 \%$ is the maximum that polystyrene culture dishes can deform elastically before plastic deformation occurs. Fig. 2B and $\mathrm{c}$ clearly indicate that stress lines form in the plastic after 3500 cycles; however, few dishes have cracked so far. 
The strain gauge readings demonstrate that the bottom of the dish is bending, with the inner surface registering compression. Since the tendon cells are attached to the surface of the Petri dish, it is assumed that these cells experience the inner surface strain. It should be pointed out that the cells are attached to the surface that undergoes a decrease in length along the diameter followed by an increase back to the original length as the pressure is released.

Data in Table 1 indicate that tendon cells in culture respond to a regimen of cyclic compression by altering protein synthesis. Actin is a key cellular component involved with myosin in cell movement and contraction (Pollard \& Weihing, 1974). Tubulin is a major cytoskeletal element involved in maintenance of cell form (Olmsted \& Borisy, 1973).

Superficial flexor tendons in the horse in vivo are subjected to strains up to $12 \%$ and strain rates up to $200 \%$ per second (Henrick, Kingsburg \& Lou, 1978). However, collagen, the load-bearing structure in tendon will only undergo $1-2 \%$ extension under physiological conditions (Lanir, 1978). Stress-strain relations are reversible in tendons if strain does not exceed 2-4\% (Abrahams, 1967).

Somjen et al. (1980) have demonstrated short-term effects of tension in vitro on osteoblasts. Cultured osteoblasts subjected to a single, sustained force applied by an orthodontic device glued to the bottom of a Petri dish respond by producing CAMP and prostaglandin $\mathrm{E}_{2}$ within minutes (maximum production at $20 \mathrm{~min}$ ). Banes, Enterline, Bevin \& Salisbury (1981) drew the analogy between the osteoblast and tendinocyte, each bound in a highly collagenous matrix and each subjected to tension in vivo. The tendon is also subjected to a compressive force when tension is applied.

Emphasis on the nature of collagen and elastin in tendon has minimized consideration of the structural or biological roles that other proteins, and even the resident tendon cells themselves, may have in vivo. Tubulin and actin may be involved in vivo in response to the physiological range of compression and tension, and appear to be altered in vitro in response to cyclic compression.

This work was supported by NIH grants AM30952, AM30478, DE02668 and USPHS grant 5-SO1-FR-05406. We thank Ms Kathy Donlan for technical support.

\section{REFERENCES}

Abrahams, M. (1967). Mechanical behavior of tendon in vitro. Med. biol. Engng 5, 433-443.

AREM, A. J. \& MADDEN, J. W. (1976). Effects of stress on healing wounds: I. Intermittent noncyclical tension. J. Surg. Res. 20, 93-102.

Banes, A. J., Enterline, D., Bevin, A. G. \& Salisbury, R. E. (1981). Effects of trauma and partial devascularization on protein synthesis in the avian flexor profundus tendon. 7 . Trauma 21 , 505-512.

BONNER, W. M. \& LASKEY, R. A. (1974). A film detection method for tritium-labelled proteins and nucleic acids in polyacrylamide gels. Eur. F. Biochem. 46, 83-88.

HenricK, W. C., KingsBurg, H. B. \& Lou, D. Y. S. (1978). A study of the normal range of strain, strain rate and stiffness of tendon. F. Biomed. Mat. Res. 12, 877-894.

LANIR, Y. (1978). Structure-strength relations in mammalian tendon. Biophys. Ү. 24, 541-554.

Olmsted, J. B. \& Borisy, G. G. (1973). Microtubules. A. Rev. Biochem. 42, 507-540. 
OoKA, H. (1970). The proliferative response of mouse epidermal cells to injury observed in vitro. Ann. Zool. Fap. 43, 70-78.

Pollard, T. D. \& WeiHING, R. R. (1974). Actin and myosin and cell movement. CRC Crit. Rev. Biochem. 00, 1-65.

Ristow, H., Holley, R. W. \& Messmer, T. O. (1978). Regulation of growth of fibroblasts. J. invest. Dem. 71, 18-23.

Somjen, D., Binderman, I., Berger, E. \& Harall, A. (1980). Bone remodeling induced by physical stress is prostaglandin $\mathrm{E}_{2}$ mediated. Biochim. biophys. Acta 637, 91-100.

SyKes, B. C. \& BAILEY, A. J. (1971). Molecular weight heterogencity of symbol the $\alpha$-chain subunits of collagen. Biochem. biophys. Res. Commun. 43, 340.

(Received 31 October 1984 -Accepted 21 November 1984) 